\title{
Prison and Its Impact on Recidivism
}

\author{
Amir Alahdadi ${ }^{1}$ \\ ${ }^{1}$ Islamic Azad University, Iran \\ Correspondence: Amir Alahdadi, Master of Criminal Law, Islamic Azad University, Iran.
}

Received: April 11, 2016 Accepted: May 23, 2016 Online Published: June 29, 2016

doi:10.5539/jpl.v9n5p59 URL: http://dx.doi.org/10.5539/jpl.v9n5p59

\begin{abstract}
"Imprisonment" is one the main penalties currently applied in all legal systems of the world. This penalty, as well as other penal institutions, has undergone many changes throughout history and has been evolved by several reforms to turn into its present form. However, imprisonment system has not moved towards its goals - which are "punishment", "intimidation" and "rehabilitation". Also it has adverse effects and serious damages for the society, including the impact of prison on recidivism.

Serious attention to the problems arisen from prison is a critical and essential issue that requires cooperation and coordination of triple forces and community as well as the prisoners themselves. It is not a unilateral issue which involves the prisoner community at all, but its major victim is society where recidivism disturb the peace, order and security. Thus, the goal of all criminal systems in recent years was reducing the resort to this punishment and eliminate its adverse effects and also passing several rules, regulations and bylaws or holding numerous conferences and training workshops at national and international level. In order to achieve this purpose rules and providing different solutions are imposed.
\end{abstract}

Keywords: prison, crime, punishment, recidivism

\section{Introduction}

Healthy society is a society in which people feel safe; safety refers to being safe from the threat of death, disease, poverty and accidents. In other words being safe from any factor that destroys the peace of man. Similarly, one of the factors leading to the erosion of a security sense and damage for the community is the consensus crime. Moreover, crime is not only a factor for disturbing public order, but also an obstacle to economic, social and political growth of community. Crime is to violate the laws of the country for which punishment has been determined.

Along with human development and great changes in society, especially industrialization developments, cultural transformations, changes in lifestyle, changes in the construction and function of social institutions, all causes social problems to occur. In most cases, people who commit crimes lose irreparable opportunities in terms of job, education and family. Such negative background has a great impact on their lives. They are generally ignored from the community, family, friends, formal and informal institutions, and the possibility of returning to society as an ordinary person is facing serious problems. Statistics show that the majority of people who once imprisoned, find it hard to return to the community and would commit a crime again and return to prison. Researches show that prison is shattering and disappointing for many prisoners because of the negative effects thy experienced in the prison. Insufficient corrective measures and rehabilitation of prisoners means that they are better prepared to commit a crime when they left the prison in comparison to the time of arrival. International community, especially developed countries, have concluded that prison cannot have a decisive role in reducing crime. It has been repeatedly stated that, in practice, prison has become the school of crime. In addition, numerous empirical studies have confirmed this theory that lawful penalties reduce the value of obedience and adherence to laws and then committing crimes in the future. Evidence shows that the deviation of an individual is not a personal issue, but if we track the causes and consequences of this issue, we'll observe that this action is a part of a social system or movement that threatens the lives of others and the whole system.

\section{The Definition of Prison and Prisoner}

Prison means "Habs" and "Sejn" in Arabic. Some verses of Quran also mentioned this word, such as "Rab al-sejn Ohebo ela" and "Tohsebonaha min baa'd al-sejn". Anyway, this word means that the prisoner is deprived of properties and freely movement. 
In terminology of criminal law, imprisonment means to deprive freedom and authority of individual within a certain or infinite period of time so that there is no expectance of freedom. In case there is the expectance of freedom, it is called detention not imprisonment. So the criterion of prison in criminal law is to prevent and deter of liberty and properties.

Hence, prison is a place where the offenders and criminals are kept under a written warrant of judicial authority temporarily or permanently for a certain time with the aim of reforming, correcting and treating social disorders. So it can be said that prison is a corrective mechanism to reform human.

Prisoner is someone who is in prison due to legal grounds, including an accused or sentenced to imprisonment or a person who has been imprisoned due to financial conviction.

Crime is a behavior contrary to individual and social interests against which judicial organs of authority and divine governance determine a penalty. In another definition proposed by the French lawyers in which a mental element has been included in the definition of the crime in addition to legal and material elements. In this definition, crime is "transgressive manifestation of an individual's will in contrary to the law for which punishment is imposed."

Usually, a new person who enters social environment of prison is likely to interact and likes to be accepted by others. So, he/she accepts the norms and values of prisoners and compares himself by them and thus tends to be encouraged. Although there are cultural - sport, recreation programs and employment services in prisons to somehow fill their time. However in practice, usually the criminal leaves prison with a high rate of crime knowledge rather than learning positive cases under certain circumstances.

In societies where the goals are severely emphasized and the means are not considered that much, people learn to take the most efficient means in terms of technique to achieve the goals, even if the means are illegitimate.

In practice, prison, does not provide what it claims and it is far from its establishment goal. The aim of the eighteenth century people who had imposed classes and categories for prison was to include the aspect of exemplary punishment. The nineteenth century men believed that solitary confinement makes the sentenced remorse and help him to make decision to continue living in dignity. Man of the twentieth century also knows prison as a place and mean for social rehabilitation of sentenced, but the truth is that all these hopes are gone. Prison should be the main instrument of reaction against delinquency, but it has become a school for recidivism from the very beginning.

Regarding judicial actions taken on criminals who commit crimes again after their release from prison, there are two major policies: policy of elimination of prison and policy of decriminalization.

The policy of decriminalization is based on a thought that criminal shouldn't be taken to the prison and some crimes must be excluded from crimes and treated with formal mechanisms, because prison automatically provide the grounds for crimes. It has happened abundantly in the past that amateur criminals in prison has been turned into professional criminals. So decriminalization policy is a true policy that its application could be useful for certain crimes. The policy of eliminating prison completely removed the country's prisons and all prisons become detention house.

\section{Types of Prison}

There are various prison types that here we mention some of them:

\section{A) short-term confinement}

Short-term prison has a relative and theoretical concept. The meaning not only varies from country to country, but also within a country over time.

International Association of Criminal Law defines short-term confinement as the confinement that not exceeds 3 months. Some countries such as Belgium, Finland, Japan and Britain, consider short-term confinements as the sentences less than 6 months.

A group of lawyers from different countries believe that the disadvantages of short-term imprisonment are so abundant that it should be called as "a medicine worse than the treatment."

Some of the researches believe that such confinement must be eliminated and some others believe that such confinement should be reformed while maintaining its principal. Some people also believe that the criminal must be kept in free spaces in different forms that the most important of them is retrieval system with test and care.

\section{B) Long-term confinement}

It is used in contrary to short-term confinement and varies in terms of the definition of short-term confinement; 
i.e. if a criminal system knows short-term confinement less than 3 months, so long-term confinement is more than 3 months; and if the criterion is six months, then long-term confinement is more than 6 months.

\section{C) Solitary confinement}

It is fully in opposite of shared prison and include complete isolation of criminal on a day; i.e. prisoner is kept in a cell where he eats, works and sleeps, and when he comes out, he must use of blindfolds in the corridors so that those who encounter with him could not recognize him.

\section{D) Shared prison}

Shared prison is opposite of solitary confinement; and prisoners live together during days and nights and sleep in shared dorms. They eat in shared halls and work together in large workshops without obligation to be silent.

\section{E) Mixed prison}

This type of confinement was first organized and implemented in 1816 in Aborn Prison (New York State). This type of sentence is a combination of two previous confinements, including solitary confinement regime consisted of isolation at night. Also the regime of shared prison during the day to work, eat, and exercise or leisure. The criminal spends the night in isolation, but he is only mentally isolated during the day, because he must live and work with others in silent. The most important characteristic of this confinement is keeping silent.

However, prison with a variety of other confinements such as open prisons, closed prisons, single prisons (normal or non-working), prison with work and service, educational prisons, prisons for soft crimes, working camps for convicted to short-term confinements and so on.

\section{Philosophy of Prison}

Genesis of prison is apparently derived from three things:

1) The love of human to freedom and the fact that deprivation of liberty is a painful torture for a man. So they used prison as punishment.

2) Sometimes they take a man into prison in order to prevent his detriment to the community.

3) Sometimes a murder happens and some people are accused. If they were left free, the major criminal might escape and go to a safe place. Thus, all accused persons were detained temporarily for investigation.

The main philosophy of prison is: 1 . Punishment; 2. Prevention from evilness; 3. Preventing criminal from escape.

Specific and objective goals of prison within the duties of the Organization for Prisons and Security and Corrective Measures

A) Maintenance of the defendants and sentenced to prison, according to the written order of judicial authorities and in accordance with relevant laws and regulations;

B) Administration of all affairs of prisons, training and vocational centers, detention centers, and Security and Corrective centers, industrial, agricultural and service institutions and other related centers;

C) Establishment of training and vocational centers, prisons, detention centers and industrial, agricultural and service institutes and other agencies needed for maintenance, rehabilitation, vocational and employment of convicted and sentenced people.

D) Doing new criminological researches to improve wardership methods and services;

E) Policy making, management and supervision of all matters relating to prisons and affiliated institutes and centers;

F) Preparation of a draft for necessary laws and regulations, and proposing to the competent judicial authorities;

G) Provision of appropriate and necessary facilities to takeover rehabilitation affairs such as amendment, guidance, training and re-adaptation of convicted;

H) Doing consulting services as well as public assistance, charities and planning for the correct use of these contributions with the aim of improving the prisons and helping the convicted, or their family;

I) Attracting any assistance such as donations, charities and planning for the correct application of these contributions aimed at improvement of convicted prisoners and their families;

J) Policy making and planning all affairs relating to employment and vocational training of criminals and independence of vocational training centers and prison and its affiliated; 
K) Preparing needed statistics and information from prisoners under the supervision of scientific methods to be used in executive affairs, policy making and criminological studies and publishing them for criminal statistical year;

L) Preparing and suggesting the names of convicts eligible for amnesty and presenting them to the Board of Pardons;

M) Planning for care convicts after leaving in collaboration with relevant organizations;

N) Training staff in line with the principles of modern penology and judicial development policies of the judiciary

\section{The Role of Prison in Rehabilitation and Prevention of Recidivism for Prisoners}

In terms of education, the pivotal task of prison is rehabilitation and renovation of prisoners. The period of imprisonment is an opportunity for the prisoner to gain technical skills and utilize them for a job after releasing from prison. If the prisoner had a particular career or occupation before that, he can enhance the technical capacity using the training facilities.

So what remains is to stimulate enthusiasm for learning among prisoners and satisfying them to participate in these programs. Together with implementation of incentive and punishment policies in prisons, it will have some success. One of these policies that can bring the incentive for harder efforts in prison is giving more advantages to the prisoners who are interested in scientific trainings and also depriving those prisoners who escape from working. This right, however, must be preserved for the community that it must take all its efforts to "reform criminals" and adapt offenders with normal life.

Regarding to the issue of penalties for the offenders repeating different crimes several times, the weakness of the laws can be the main reason for recidivism. First of all, it should be specified the punishment purpose. Unfortunately, today, despite the policy of judiciary, the number of prisoners is still very high and unfortunately the facilities of prisons are with very limited.

The purpose of punishment is to reform a person who committed a crime and find the opportunity of living again in the society so that they could gain what they have lost. But, the sentenced person in the society is usually disillusioned and desperate and then takes defensiveness to the people around. It is while the purpose of punishment is to reform the criminals so that they could find the opportunity of living again in the society.

There is a certain classification of prisoners in our country. Accordingly, it is decreed that prisoners are classified based on sex, age, criminal record, personality, job and type of crime; but unfortunately, this issue is not taken seriously due to lack of infrastructure space.

\section{Rehabilitation Activities in Prison}

\subsection{Cultural and Training}

Cultural programs in prison include a series of educational initiatives (Literacy Movement to the University), religious programs, art and physical education, which are developed with an approach to normalize the prisoners' behavior. These programs are replaced with controlling social abnormalities of prisoners using religious values-based and Quranic programs, awareness and action.

Religious discussions including courses of Ahkam, Quran and religious foundations have significant effects on the growth and prosperity of prisoners. It also reduces adverse effects and leads to the health of soul and body of prisoners. The cooperation between prison and judiciary leads to the identification of solutions. Application of policies is necessary to reduce the criminal population. The main concern of the organization of prisons is achieving educational goals and of course, implementation of this goal is of a special place.

\subsection{Employment and Vocational}

Based on Article 122 of Execution Regulations, the Organization of Prisons has to provide and spend necessary funds to develop various issues including: rehabilitative programs, reduce damages and shortcomings inside the prison, contribute to solve material and spiritual problems of convicts and their families, and achieve self-sufficiency from the cooperative and training enterprise, attracting public funds and charitable institutions or income from industrial, agricultural, service and cultural institutions as well as approved budget.

Also, in Article 123 and Article 124 of the above Regulations, the organization can use the facilities of organization, public aid, the participation of banks, government agencies, cooperatives and the private sector to create job opportunities for volunteer convicts. Then, the volunteer defendants and convicts will be employed in workshops inside prisons or industrial, agricultural and service institutions outside the prison after doing the 
necessary tests and identifying their talent and expertise with the consent of the Council on classification and compliance of provisions.

Prisoners and convicts can make handicrafts in their free times in dorms with the consent of the prison boss. Raw materials of such works are provided exclusively through the central store of prison.

\subsection{After-Release Care Center}

All activities performed to reduce social harms (about prisoners' families) and after-release care as well as completion of the process of Education and Reform (about the prisoner released) to achieve an optimal conditions and acceptance of individual in society.

\subsection{Furlough}

Furlough is determined by prison regulations. It can be said that furlough is not a right for prisoner, but also a privilege and incentive which is granted to the individual in case of eligibility, in accordance with Article 213 of the Executive Regulations of Organization for Prisons and Security and Training Measures.

If the judge supervising prison sees that a person has committed a crime several times and he/she will do it again in furlough, then he may not allow.

\section{Conclusion}

Prison has become a complex topic in many countries. Now, the basics of reforming punishment laws by new methods; its social, economic and political dimensions; assessment of government's performance in terms of its impact on social control policies; liberty-deprivation punishment laws; the number of prisoners which is increasing all around the world; and different social reactions are in the front of a certain government to be selected; studying and criticizing the severity of exploitation of prisons and privatization of the Organization of Prisons and other items are leading governments to reduce recidivism.

Regarding the lack of facilities and insufficient experts in prisons, the prisons are not inefficient to prevent from crime, but also expand recidivism, variety of committing crimes, and train criminal techniques. Although the purpose of imprisonment is punishment of prisoners and a lesson for others, in practice what was expected has not happened, and unfortunately, delinquency and recidivism has been increased.

Therefore, it is necessary to reduce sending the criminals who don't need corrective programs to prison by adopting decriminalization measures and policies, and implementing penal policies and substitutions for imprisonment. On the other hand, take all attempts to reform the remaining prisoners who should really be in prison by spending the costs dedicated to prisons and application of specialists and also exact planning in consistent with wardership. In addition the criminals who have been affected by the corrective programs should be released before the expiry of their punishment by adopting measures such as parole and amnesty.

Anyway, in this paper we have emphasized on two things:

1) Preparing a personality profile for all defendants who are under prosecution and also developing social work departments in police stations

2) Enabling after-release departments and centers

Continuing supportive measures for needful criminals and controlling measures for the criminals who are likely commit crimes in the future is possible only by the mobilization and participation of all institutions and people, and using preventive measures by legislature of Islamic Republic of Iran not reduce crime in the community

\section{References}

Abazar Foumashi, M. (2008). Terminology of criminal terms. Andishe Asr Publishing.

Ansel, M. (1996). Social defense, translated by Mohammad Assyrian and Ali Hussain Najafi Abrndabadi, Tehran University.

Ardabil, A. (2006). Public criminal law (1st Vol.). Mizan publishing.

Ashori, M. (2003). Alternatives to prison or intermediate punishment. Tehran. Publishing trends. Printing. [Persian].

Bernburg, J. G., \& Krohn, M. D. (2003). Labeling, life chances anf adult crime: the direct and indirect effect of official intervention in adolecences on crime in early in adulthood. Criminology, 41(4). http://dx.doi.org/10.1111/j.1745-9125.2003.tb01020.x

Eeman, R. B. (1996). Why do so many young American men commit crime and what might we do a bout it? $J$ 
Econ Perspect, 10(1).

Executive Regulations of Organization for Prisons and Security and Training Measures.

Hatami Khaje, N. (2004). Socialization of prisoners. Proceedings of the First International Conference on the reduction of the prison sentence, Tehran. Rahetarbiat Publications. [Persian].

Hezar Jaribi, J., \& Safari, R. (2010). Factors influencing crime (Case Study prisoners Central Province). Journal of Social Sciences, 46, [Persian].

Iran Newspaper, Number 5092, Date 2012, Page 13.

Jaaffari Langroodi, M. J. (1997). Terminology of law (6th ed.). Ganje Danesh publishing.

Kafashi, M., \& Eslami, A. (2009, Fall). Factors influencing the occurrence of crime and return to prison in North Khorasan Province. Journal of Social Research, 2(4), [Persian].

Koldi, A. (n.d.). Deviance, crime and prevention. Journal of Social Welfare, 2(3).

Mahdavi, R., \& Pakideh, F. (2008). Assessment of familial and social factors on return to prison. Eslah \& Tarbiat.

Najafielmi, M. (2004). Assessment of recurrence of theft among thieves record in Tehran Province. Computer Research Center of Islamic Sciences, 6(1).

Norai, E., \& Mahbob, S. (2010). Sociological study of crime among youth and social factors that affect Ilam (Case Study: Jail Ilam). Social Security Studies. [in Persian].

Overview of Fourth Development Plan for the country's wardership.

Robertson, I. (2003). Introduction to community, translated by Hussein Behravan, Mashhad, Astan Qods Razavi Publications.

Sedighservestani, R. (2004). Social Pathology. Tehran. Printing. An Publications. [Persian].

Western, B. (2002). The impact of incareceration on wage mobility and inequality. Am Sociol Rev. http://dx.doi.org/10.2307/3088944

Western, B., Kling, J. R., \& Weiman, D. F. (2001). The labor market consequence of incarceration. Crime delinq, 47(3). http://dx.doi.org/10.1177/0011128701047003007

\section{Copyrights}

Copyright for this article is retained by the author(s), with first publication rights granted to the journal.

This is an open-access article distributed under the terms and conditions of the Creative Commons Attribution license (http://creativecommons.org/licenses/by/3.0/). 